\title{
NDRG4 Gene
}

National Cancer Institute

\section{Source}

National Cancer Institute. NDRG4 Gene. NCI Thesaurus. Code C111838.

This gene is involved in vascular smooth muscle cell mitogenesis, spatial learning and neuronal survival. 